\title{
Distribution \& Preference of Entamopathogenic Bacteria across Different Soils of Karnataka
}

\author{
Sonia Bohra ${ }^{1}$, M. K. Shivaprakash ${ }^{2}$ \\ Department of Agril. Microbiology, UAS(B), G.K.V.K, Bangaluru-65
}

\begin{abstract}
Photorhabdus is an effective biological weapon against insect pest of crop plants which act as syringe like mechanism and triggered death of pests with in $48 \mathrm{~h}$. Photorhabdus luminescens is a symbiont of nematodes and a broad spectrum insect pathogen. This study aims to collect Entamopathogenic nematode (EPN) from different agro climatic zones of Karnataka and isolate Photorhabdus luminescens from them as it act as effective biocontrol agent against numerous insect pests. Entamopathogenic nematodes are collected from cultivated and noncultivated areas of different agro climatic zones of Karnataka using $\underline{G}$. mellonella, a host susceptible to EPN by baiting method. Percent infection of $\underline{G}$. mellonella larvae by EPN in soil across different locations was recorded. Photorhabdus bacteria were isolated and identified using standard synaptic keys according to Bergey's Manual of Systematic Bacteriology. It was further cofirmed using $16 \mathrm{~S}$ rDNA primer. The population of endosymbiont Photorhabdus found less in non cultivated land as compared to cultivated soils of Karnataka.
\end{abstract}

Keywords: Distribution, P. luminescens, EPNs, Heterorhabditis, agroclimatic zone, infection

\section{Introduction}

Soil is the natural habitat for EPNs where they are associated with various insects. They can be extracted from soil by baiting with susceptible insects. The nematode population in soil varies according to the environmental conditions and is favored by factors such as high soil moisture, temperature and abundance of insects in the area. The larval mortality was observed daily or in about a week's time (Hara et al., 1993). Dead larvae are washed in distilled water and put on White's trap for extraction or dissected out to see the presence of nematodes. The coloration of dead larvae gives some indication about the presence of EPNs (Hominick and Briscoe, 1990). Annual medium temperature and rainfall had little association with the presence of nematode, Heterorhabditis indicus isolated from soils in Tamil Nadu (Poinar et al., 1992). Some entomopathogenic nematodes have been isolated from insects naturally infected in the field, but they are most commonly recovered from soil by baiting with susceptible insects. (Bedding and Akhurst (1974).

Photorhabdus luminescens is an insect pathogenic bacterium that is symbiotic with entomopathogenic nematodes mainly Heterorhabditis species and act as a potential biocontrol agent that infects important crop pests (Poinar, 1979). The nematode worm burrows into insect prey and regurgitates Photorhabdus, which goes on to kill the insect. The nematode feeds off the growing bacteria until the insect tissues are exhausted, where upon they reassociate and leave the cadaver in search of new prey. It also has the potential similar to that of Bacillus thuringiensis which is now commercially exploited. The work on Photorhabdus luminescens is not as extensive as Bacillus thuringiensis work since its isolation is not very simple as it is a symbiont of entomopathogenic nematodes. However once the bacterium has been isolated it can be cultured like any other common bacteria (Akhrust, 1986). It is important to develop the next generation of biocontrol agents in order to be one step ahead of the insects that tend to develop resistance to existing biopesticides.

\section{Methodology}

1) Collection of samples: Soils from different locations of cultivated and non cultivated areas of Karnataka mainly from Devanahalli, Doddaballapur, Hoskote, Whitefeild, Sarjapur, University campus, Nelamangala, Nagarahole, Virajapet, Madikeri, Suliya, Puttur, Nelvadi and Sankleshpura are collected and brought to the laboratory of University of Agricultural Sciences, GKVK, Bangalore-65. Fields of tomato, Fieldbean, French bean, chilli, marigold, capsicum, cowpea, chickpea, ground nut, lady finger, ragi, pigeon pea, cabbage and maize were explored for collection of soil samples across different cultivated areas. Moisture content of soil is maintained as nematode need it for survival.

2) Isolation of EPNs from soil: Isolation of EPNs is carried out using Galeria mellonella, a host susceptible to EPNs, by baiting method described by Bedding and Akhurst (1975). G. mellonella was reared in lab using artificial diet containing Maize, Wheat, Honey, glycerol, Milk powder, Yeast, Protein and Vitamin. Small plastic vials with last instar larvae of $G$. mellonella were placed in the polythene bag containing soil at a depth of $10 \mathrm{~cm}$. The nematode traps are harvested at $4^{\text {th }}, 7^{\text {th }}$ and 12 th day interval to know the percent infectivity of $G$. mellonella larvae to EPNs. The infected larvae were washed with distilled water and kept on white's trap to collect released nematodes.

3) Isolation of Symbiotic bacteria from EPNs: The infective juveniles are surface sterilized with 0.1 percent hyamine and rinsed 2-3 times with distilled water in order to remove traces of hyamine. Three to five instar larvae of greater wax moth are released into petriplate with moist filter paper disc with infective juvenile's suspension and it is incubated at $28^{\circ} \mathrm{C}$ for 2 days. Dead larvae are surface sterilized with 70 percent ethyl alcohol and rinsed 3-4 times with sterile water. Later, the larvae passed over the flame using sterile forceps for few seconds. Then they are dissected and a drop of haemocoel from insect cadaver is streaked on NBTA medium and incubated at $28^{\circ} \mathrm{C}$ in the dark for $24-48 \mathrm{~h}$. 


\section{International Journal of Science and Research (IJSR) \\ ISSN (Online): 2319-7064 \\ Index Copernicus Value (2013): 6.14 | Impact Factor (2015): 6.391}

4) Identification of symbiotic bacterial isolates: Bacteria were identified with the help of standard synaptic key of Bergey's manual of systematic Bacteriology. Numerous test like Catalase, Urease, Lactose fermentation, Gram reaction and motility tests were performed and observations was recorded. The cultures are further identified on molecular basis with the help of $16 \mathrm{~s}$ rDNA primer and sequenced. DNA was isolated according to the method of Sambrooke et al., (1989).

\section{Result and Discussion}

Soil samples were collected from selected agro climatic zones of cultivated and noncultivated locations of Karnataka. Percent infection of G. mellonella larvae by EPN was recorded across different locations of Karnataka. Entomopathogenic nematodes are known to be compatible with other bio-control agents, fertilizers, herbicides and plant protection chemicals. Thus, encouraging their use in integrated pest and disease management programmes (Dutky et al., 1964). Tóth (2006) isolated Heterorhabditis and Steinernema by using late instar larvae of Galleria mellonella and Tenebrio molitor as bait. He collected 89 soil samples in 2003 and 200 soil samples in 2005 from different parts of Hungary. Application of urea, ammonium sulphate, muriate of potash (MOP) and super-phosphate as basal or top dressing to rice crop did not adversely affect the survival of nematode (Rao et al., 1975). From those EPNs, $P$. luminescens was isolated and identified. Growth of bacteria was checked on different media like NBTA (Nutrient Agar with Bromothymol blue (Akhurst, 1980). and Mac Conkey. Bacterial colonies show blue colour with NBTA while pink colour with Mac conkey media. It was further sub cultured on Nutrient Agar showing slimy whitish colonies. The bacterial isolates are found Gram negative rods showing positive tests towards Catalase test (appearance of gas bubble), Urease test (appearance of pink colour), Lactose fermentation test and motility test. Further DNA was isolated from selected isolates and amplified with 16S rDNA primer (Forward: 5'AGAGTTTGATCCTGGCTCAG 3', Reverse: 5 'ACGGCTACCTTGTTACGACTT 3') and sequenced. The 16S rDNA sequences showed 98\% similarity with that of $P$. luminescens subsp. akhurstii strain EG2. In soil samples of cultivated areas, $P$. luminescens was found highest in tomato fields of Doddaballapur i.e., 20\% while least was recorded with soil samples of Cowpea fields of Whitefield. While in case of selected noncultivated area, $P$. luminescence was recorded maximum with $7.5 \%$ from soil samples of Suliya. The above results interpreted that Distribution of $P$. luminescence in nature is very less, hardly $20 \%$ and it was more distributed over cultivated lands in comparison to non cultivated areas may be due to that they may get their feed easily for multiplication.

\section{Conclusion}

Photorhabdus luminescens is an entomopathogenic bacterium and provide effective biological control to insect crop pests. It is endosymbiont with Heterorhabditis sps. nematode and the population of these organism is found less in non cultivated lands while they found more in cultivated lands across selected locations of Karnataka.

\section{Future Scope}

This piece of work would provide an idea about the distribution and preference of Entamopathogenic bacteria across different areas of Karnataka.

\section{Acknowledgement}

We are thankful to Department of Biotechnology New Delhi sponsored DBT-UAS Biotech Hub, No. BT/INF/UAS Bangalore/ 2011 for proving the funds and all the necessary facilities for completion of this piece of work.

\section{References}

[1] Akhurst,R.J., (1980): Morphological and functional dimorphism in Xenorhabdus spp., bacteria symbiotically associated with the insect pathogenic nematodes, Neoaplectana and Heterorhabditis. J. Gen. Microbiol. 121, 303-309.

[2] Akhurst,R.J. (1986): Controlling insects in soil with entomopathogenic nematodes. In: Fundamental and applied aspects of invertebrate pathology. (Eds: Samson,RA; Vlak,JM; Peters,D) (Proceedings of the fourth international colloquium of invertebrate pathology, Veldhoven, The Netherlands.) Foundation of the Fourth International Colloquium of Invertebrate Pathology, Wageningen, The Netherlands, 265-267.

[3] Akhurst R.J.(1982). Antibiotic activity of Xenorhabditis spp., bacteria associated with insect pathogenic nematodes of the families Heterorhabditidae and Steinernematidae. J. Gen. Microbiol., 128: 3061-3065.

[4] Bedding R.A. and Akhurst R.J. (1975). A simple technique for the detection of insect parasitic nematodes in soil. Nematologica, 21:109-110.

[5] Bedding R.A. and Akhurst R.J. (1975). Parasitization of scarabs by nematodes. CSIRO Div. Entomol. Ann. Rep. 1971-71.103-104

[6] Boemare N.E. and Akhurst R.J., (1988). Biochemical and Physiological characterization of colony form variants in Xenorhabdus spp. (Enterobacteriaceae). Journal of Genetic Microbiology, 134; 751-761.

[7] Dutky, S. R., J. V. Thompson and G. E. Cantwell (1964). A technique for the mass propagation of the DD-136 nematode. Journal of Insect Pathology 6, 417422.

[8] Ffrench- Constant R.H., Dowling A. and Waterfield N.R., (2007). Insecticidal toxins from Photorhabdus bacteria and their potential use in agriculture. Toxicon Review, 49: 436-451.

[9] Forst S., Dowds B., Boemare N. and Stackebrandt E., (1997). Xenorhabdus and Photorhabdus spp.: bugs that kills bugs. Annu. Rev. Microbiol., 51: 47-72.

[10] Gatsogiannis C., Lang A.E., Meusch D., Pfaumann V., Hofnagel O., Benz R., Aktories K., Raunser S., (2013). A syringe - like injection mechanism in Photorhabdus luminescens toxins. Nature, 195: 520-523.

[11] Hara AH, Kaya HK, Gaugler R, LeBeck LM, MelloCL., (1993). Entomopathogenic nematodes for biological control of the leaf miner, Liriomyza trifolii (Dipt., Agromyzidae) (Rhabditida: Steinernematidae). Entomophaga. Vol. 38: 359-369. 


\section{International Journal of Science and Research (IJSR) \\ ISSN (Online): 2319-7064 \\ Index Copernicus Value (2013): 6.14 | Impact Factor (2015): 6.391}

[12]Heidi G.B., David J.C., (2007). Mutualism and Pathogenesis in Xenorhabdus and Photorhabdus: two roads to the same destination. Molecular Microbiology, 64: 260-268.

[13] Hominick W. M. \&B. R. Briscoe, (1990). Occurrence of entamopathogenic nematodes (Rhabditida : Steinernematidae and Heterorhabditidae) in British soil. Parasitology, Vol. 100 : 295-302.

[14] Poinar G. O. (1992). Glaser, Rudolph. W. (1888-1947)A pioneer of steinernematid nematodes. Journal of invertebrate pathology. Vol $60: 1-4$.

[15] Poinar G. O. and Thomas G. M. (1979). Xenorhabdus gen. nov., a Genus of Entomopathogenic Nematophillic Bacteria of the family Enterobacteriaceae. Int. J. Syst. Bacteriol., 39: 352-360.

[16] Rao J., Rao Y.S., Nandakumar C. and Prasad J.S. (1975). Investigations on the white tip nematodes
(Aphelenchoides besseyi Christie,1942) of rice (Oryza sativa L.). Indian J. Nematol., 5: 62-69.

[17] Sambrook,J., Fristch E.F., Maniatis T.,(1989). Molecular Cloning: A Laboratory manual, $2^{\text {nd }}$ edition, CSH laboratory press. Vol. 1, section 6 .

[18] Sicard M. et al., (2008). Isolation and identification of entomopathogenic nematodes and their symbiotic bacteria from Herault and Gard (South France). Journal of invertebrate Pahology, 98: 211-217.

[19] Tímea Tóth (2006). Collection of entamopathogenic nematodes for the biological control of insect pests. Journal of fruit \& Ornamental Plant Research. Vol. $14(3): 225-230$

[20] Waterfield, N.R.; Ciche, T.; Clark, D., (2009). Photorhabdus and a host of hosts. Annu. Rev. Microbiol., 63: 557-574.

Table 1: Percent infection found across cultivated areas of Karnataka

\begin{tabular}{|c|c|c|c|c|c|c|c|c|c|c|}
\hline Locations & $\begin{array}{l}\text { No. of } \\
\text { traps }\end{array}$ & \multicolumn{2}{|c|}{$4^{\text {th }}$ day } & \multicolumn{2}{|c|}{$7^{\text {th }}$ day } & \multicolumn{2}{|c|}{$12^{\text {th }}$ day } & $\begin{array}{l}\text { Total no } \\
\text { sampled }\end{array}$ & $\begin{array}{c}\text { Total no. } \\
\text { infected }\end{array}$ & $\begin{array}{c}\text { Total percent } \\
\text { infection }\end{array}$ \\
\hline \multirow{2}{*}{ Devanahalli } & 30 & 10 & - & 10 & 2 & 10 & 2 & 30 & 4 & 13.33 \\
\hline & 30 & 10 & 1 & 10 & 1 & 10 & 2 & 30 & 4 & 13.33 \\
\hline \multirow[t]{2}{*}{ Doddaballapur } & 30 & 10 & - & 10 & 2 & 10 & 3 & 30 & 5 & 16.70 \\
\hline & 30 & 10 & 1 & 10 & 2 & 10 & 3 & 30 & 6 & 20 \\
\hline \multirow[t]{2}{*}{ Hoskote } & 30 & 10 & 1 & 10 & 1 & 10 & 2 & 30 & 4 & 13.33 \\
\hline & 30 & 10 & - & 10 & 1 & 10 & 1 & 30 & 2 & 6.70 \\
\hline \multirow[t]{2}{*}{ Whitefield } & 30 & 10 & - & 10 & 2 & 10 & 1 & 30 & 3 & 10 \\
\hline & 30 & 10 & - & 10 & - & 10 & 1 & 30 & 1 & 3.33 \\
\hline Sarjapur & 30 & 10 & 1 & 10 & 2 & 10 & 2 & 30 & 5 & 16.70 \\
\hline GKVK & 30 & 10 & - & 10 & 1 & 10 & 1 & 30 & 2 & 6.70 \\
\hline Nelamangala & 30 & 10 & - & 10 & 2 & 10 & 1 & 30 & 3 & 10 \\
\hline
\end{tabular}

Table 2: Percent infection found across noncultivated areas of Karnataka

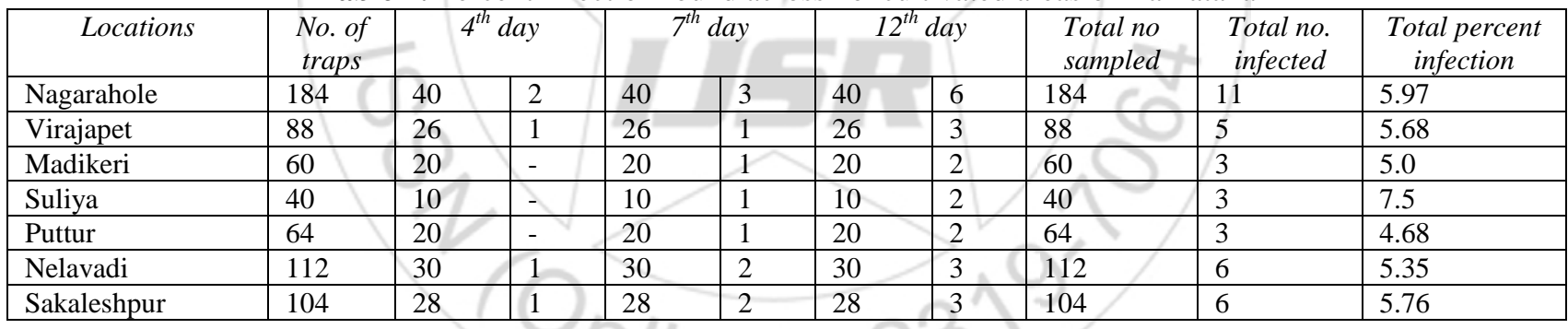

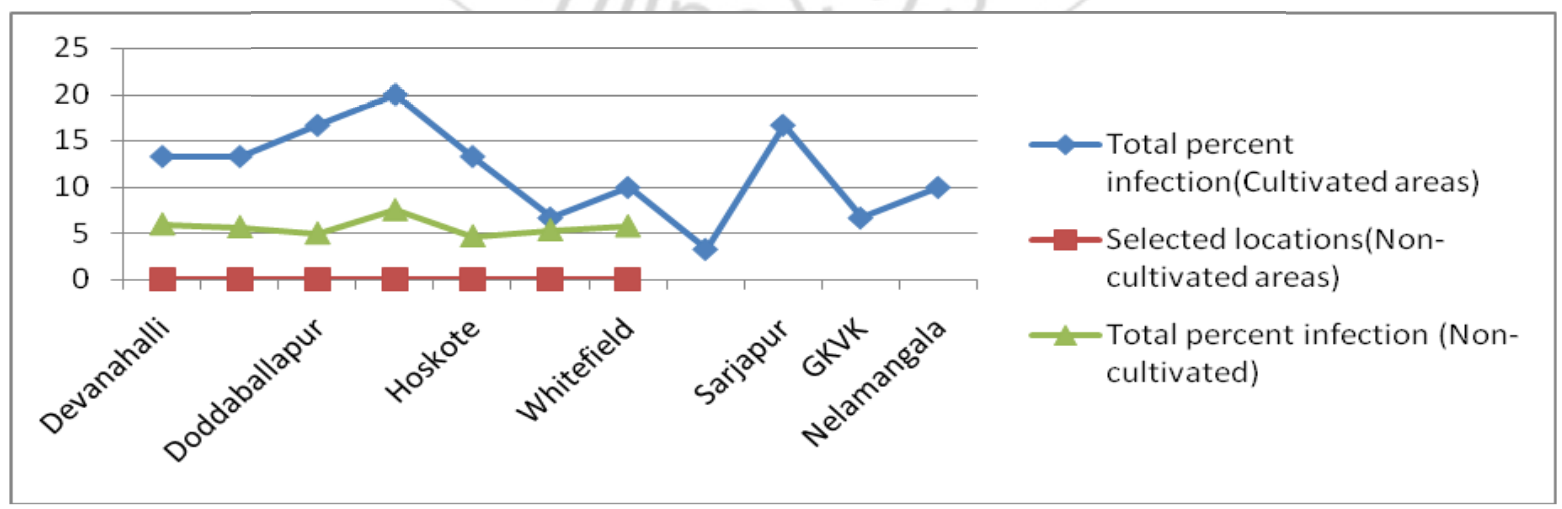

Graph: Percent infection across selected locations 